\title{
Women Migrant Workers in Fiqh Perspectives
}

\author{
L. Lutfiyah, ${ }^{1}$ Nurdien Harry \\ Kistanto, ${ }^{2}$ Muhammad \\ Akmaluddin 3 \\ 1,3Universitas Islam Negeri Walisongo, \\ Semarang; ${ }^{2}$ Universitas Diponegoro, \\ Semarang-Indonesia
}

Corresponding Author: L. Lutfiyah, email: lutfiyah@walisongo.ac.id, J. Prof. HAMKA, Fakultas IImu Tarbiyah dan Keguruan, Universitas Islam Negeri Walisongo Semarang, Jawa Tengah 50185

\begin{abstract}
The purpose of this study is to find information about the law of a wife to be a migrant worker from the perspective of fiqh. This study is qualitative research using library research and uses the fiqh approach. Data sources come from primary and secondary sources. The primary source functions as the main source, obtained by tracing the book of jurisprudence by analyzing the content (content analysis). Secondary sources function to support primary sources obtained through books, journals, and other important documents. The result is that the husband must rethink to permit wives who want to become migrant workers. Changes in Islamic law against migrant workers can occur if they meet the requirements including time, place, intention, and custom. The proof of sadd al-dhari'ah serves to inhibit the rate of sending women migrant workers.
\end{abstract}

Keywords: $\quad$ women migrant workers; fiqh; sadd al-dhari'ah

\begin{abstract}
Abstrak: Tujuan penelitian ini adalah untuk menemukan informasi tentang hukum seorang istri untuk menjadi pekerja migran dalam perspektif fiqh. Penelitian ini adalah penelitian kualitatif dengan menggunakan studi kepustakaan dan menggunakan pendekatan fiqh. Sumber data berasal dari sumber primer dan sekunder. Sumber primer berfungsi sebagai sumber utama, diperoleh dengan menelusuri buku yurisprudensi dengan menganalisis konten (content analysis). Sumber sekunder berfungsi untuk mendukung sumber primer yang diperoleh melalui buku, jurnal, dan dokumen penting lainnya. Hasilnya adalah suami harus memikirkan kembali untuk mengizinkan istri yang ingin menjadi pekerja migran. Perubahan dalam hukum Islam terhadap pekerja migran dapat terjadi jika mereka memenuhi persyaratan termasuk waktu, tempat, niat, dan kebiasaan. Bukti sadd al-dhari'ah berfungsi untuk menghambat laju pengiriman pekerja migran perempuan.
\end{abstract}

Kata Kunci: $\quad$ buruh migran perempuan; fiqh; sadd al-dhariah 


\section{A. Introduction}

The problem of women migrant workers is closely related to social systems and religious norms. Women in traditional societies have domestic duties. Thus, the existence of women migrant workers is a deviation from the general norms of traditional societies. In Islamic teachings, the fulfillment of economic needs for wives and children is charged to the men as mentioned in the Quran surah al-Baqarah verse 233. Fathers must feed and clothe mothers (wives) according to their abilities ${ }^{1}$ so that women who work outside the home let alone abroad give birth to problems based on social and religious norms.

In Islamic law and Indonesian law, there is no fundamental distinction between the terms between laborers and workers. The term labor, worker, or employee in the use of Indonesian also refers to the same object, namely the person who works, although there is a slight difference in connotation between labor and worker. Sticking social attributes, for example, can only be embedded in the word worker so that they become social workers. That does not apply to the word workers and employees or employees so there are no term social labor or social employees. Likewise, there are the term commercial sex workers, but there is no mention of commercial sex workers. In this study, the terms labor and worker are used interchangeably.

According to Indonesia Law No. 13 of 2003, labor is every person who can do work to produce goods and/or services both to meet their own needs and for the community. ${ }^{2}$ Meanwhile, Indonesia Law No. 8 of 2017 concerning the Law on the Protection of Indonesian Migrant Workers states that prospective Indonesian migrant workers are any Indonesian workers who qualify as job seekers who will work abroad and are registered with district government agencies/city that is responsible for manpower affairs. ${ }^{3}$ So, migrant workers in Indonesia are all Indonesian citizens who will, are, or have done work by receiving wages outside the territory of the Republic of Indonesia. ${ }^{4}$

Women migrant workers face problems related to their social position in the community. They are projected based on social norms to take care of

\footnotetext{
${ }^{1}$ QS. al-Baqarah [2]: 233

2Law of the Republic of Indonesia, No. 13 of 2003 concerning Manpower, Chapter I Article 1 verse 2.

${ }^{3}$ Law of the Republic of Indonesia, No. 8 of 2017 concerning Protection of Indonesian Migrant Workers, Chapter I Article 1 verse 1.

${ }^{4}$ Law of the Republic of Indonesia, No. 8 of 2017, Chapter I Article 1 verse 2.
} 
household problems. But the economic pressure of the family and the opportunity for equalization with men opened the door for women to leave their domestic territory to work abroad.

This reality does not necessarily get an endorsement from the prevailing norms because the responsibility for fulfilling family needs is on the shoulders of the husband. Religious norms explicitly emphasize that the responsibility of the husband is to meet the needs of the family and the responsibility of the wife is to take care of her husband, children, and decorate the husband in moderation. ${ }^{5}$

Therefore, migrant workers are an inseparable part of the family. Even though they work to earn money for the family, they are still burdened with household responsibilities. Women migrant workers are in a dilemmatic position because ideally, they should get the rights from their husbands, but in fact, they are the ones who bear the husband's obligations.

Migrant workers contribute income for families through remittances ${ }^{6}$ work, which is popularly called remittance (remittance)..$^{7}$ This income can reduce the household economic pressure, although it has to be paid at a large social and psychological price. Women migrant workers do not receive physical or spiritual support. But they face the fact that they are still burdened with family obligations when they also have to face work risks at their place of work, such as high work volumes. Women migrant workers also face psychological pressure from employers and adjustment to different lifestyles in other countries.

Religious norms have become one of the burdens for women migrant workers, mainly concerning domestic duties assigned to women. However, domestic duties are directly proportional to the right of living which is the husband's obligation. The question is what is the status of domestic duties when the husband is unable to provide for the livelihood that is the right of women so they have to work outside the home to overseas. This paper aims to review the law of wives who work as migrant workers from the perspective of fiqh. This study is intended to reveal how Islamic law regulates the rights and obligations of migrant workers concerning the obligations as a wife.

${ }^{5}$ QS. al-Nisā’ [4]: 34; QS. al-Ahzāb [57]: 33.

6Baiq Ratna Mulhimmah, 'Penguatan Ekonomi Keluarga Melalui Pelatihan Pengelolaan Uang Kiriman (Remitan) pada Keluarga Buruh Migran di Desa Setanggor Kecamatan Prabaya Barat Daya Kabupaten Lombok Tengah', Transformasi 10, no. 1 (2014): 14.

${ }^{7}$ Putri Asih Sulistiyo and Ekawati Sri Wahyuni, 'Dampak Remitan Ekonomi terhadap Posisi Sosial Buruh Migran Perempuan dalam Rumah Tangga', Sodality: Jurnal Sosiologi Pedesaan 6, no. 3 (2014): 252-58, https://doi.org/10.22500/sodality.v6i3.8020. 
This study uses a qualitative approach based on library research. The primary data source for this study is the reference to fiqh books, while secondary sources are obtained from books, journals, and other documents that support primary sources. The analysis used is content analysis to describe the situation of the author of the book of jurisprudence when writing his opinion. ${ }^{8}$

\section{B. Wife's Rights and Obligations in the Family}

Many family problems are regulated in Islamic law. Islamic law governs the application, criteria for the bride, wedding ceremony, the right of a husband and wife, husband possessions and wife, children, divorce, and the division of inheritance. All of that shows the great concern of Islamic teachings in regulating household issues.

The rights and obligations of the husband and wife are arranged so that the division of labor is clearly defined. There are rights and obligations that a husband and wife have and have. The husband's right becomes the wife's obligation and the wife's right becomes the husband's obligation as a reciprocal relationship.

The husband must meet the needs of families, including food, clothing, education, inner living, housing and equipment, and household servants. Based on the Qur'an and Sunnah, scholars describe the obligations of the husband above. Obligations to meet the birth needs are broken down into obligations to meet the needs of food, drink, side dishes, and others. ${ }^{9}$ According to the majority Shafi'iyyah, living for his wife adjusted to the needs of the wife and husband's ability. A living is given in a day or a month at a time. The level of living is determined according to the habits and customs of each country, according to the place, era, and condition of the husband. ${ }^{10}$

The needs of other wives are also laid down in the guidelines of Islamic law. For the needs of clothing, the husband is recommended to provide clothing for his wife once a year. ${ }^{11}$ The board's needs are adequately provided by her husband according to his abilities. Home furnishings and kitchen equipment are

\footnotetext{
8James W. Drisko and Tina Maschi, Content Analysis (Oxford: Oxford University Press, 2016), 1.

9Ibnu Qudamah, al-Mughnī, 1st juz. (Beirut: Bait al-Afkār al-Dauliyah, 2004), 1986; al-Imām Abi Zakariya Yahyya bin Sharaf al-Nawāwi al-Dimasqy, Rawḍah al-Ṭālibīn (Beirut: Dār Ibn Ḥazm, n.d.), 155455.

10Wahbah al-Zuhaili, Ușūl al-Fiqh al-Islāmī (Damascus: Dār al-Fikr, 2009), 800.

11al-Zuhaili, 802.
} 
recommended to be fulfilled by husband, ${ }^{12}$ also routine needs, such as cleaning tools for bathing, such as combs, toothbrushes, soap, perfume.

Maid is not included in primary needs, but the husband provides it if the wife is not accustomed to doing housework. Therefore, the husband provides maid services for wives who cannot do homework. ${ }^{13}$

In the Quran, the husband is required to treat his wife well. Understanding of the association is quite broad, involving communication relations to the fulfillment of inner living. Jurisprudence scholars try to provide an outline regarding the question of inner maintenance. Mazhab Maliki believes that the husband is obliged to intercourse with his wife if he does not have an obstacle, without specifying the tempo of time. ${ }^{14}$

The majority of Shafi'iyyah, view that sexual relations between husband and wife are required once and see that sexual relations are a right for the husband without the imposition of time and quantity. the reason is that sexual relations are a union between lust and love that can not be used as a liability. ${ }^{15}$ On the contrary, mazhab Hanbali believes that the husband is obliged to provide inner support to his wife. The minimum frequency of sexual relations according to the Hanbali school is once every four months. ${ }^{16}$

Sociologically, the pattern of the marital relationship can be divided into, namely: the property owner's marriage pattern, head complement, seniorjunior partner, and equal partner. The first pattern is the property owner's marriage pattern. The pattern assumes that the wife belongs to the husband, as well as money and valuables. The husband's job is to make a living, while the wife's job is to provide food for her husband and children and carry out household tasks. The husband works to provide for himself and his children.

In this pattern of marriage, the wife is more positioned as the long arm of the husband. The wife embodies the husband's interests, needs, ambitions, and ideals. If the husband wants a sexual relationship the wife must comply even though the wife does not want it. ${ }^{17}$ This pattern of marriage provides limited space for the individual expression of a wife.

\footnotetext{
12al-Zuhaili, 807-8.

13al-Dimasqy, Rawḍah al-Ṭālibīn, 1557.

${ }^{14}$ Qudamah, al-Mughnī,30.

15Wahbah al-Zuhailī, al-Fiqh al-Islām wa Adillatuhu, vol. 6 (Damascus: Dār al-Fikr, 1989), 106.

${ }^{16}$ Sayyid Sabiq, Fiqh al-Sunnah, trans. Muhyiddin Syaf (Bandung: Al-Ma'arif, 1978), 113.

${ }^{17}$ Evelys Suleeman, Hubungan-Hubungan dalam Keluarga dalam Bunga Rampai Sosiologi Keluarga, ed. T. O. Ikhromi (Jakarta: Yayasan Obor Indonesia, 2004), 101-2.
} 
The second marriage pattern is ahead of complement. The pattern puts the wife as a complement to the husband. Husbands are expected to meet the needs of love and affection, sexual satisfaction, emotional support, friends, understanding, and open communication. The husband is in charge of earning a living to support the family, while the wife is in charge of managing the household and educating children. The difference with the property owner pattern, the head complement pattern, provides a portion for the wife to participate in planning joint activities. ${ }^{18}$ The husband and wife decide together with living arrangements. The husband helps his wife when needed in handling routine household matters, such as washing dishes or putting children to sleep. Although the husband does not force his will, the final decision is in the hands of the husband. ${ }^{19}$

The third pattern is the pattern of senior-junior partner marriage. According to this pattern, the wife is a complement to the husband, but the wife is placed as a partner or partner. The rise in the position of the wife, compared to the previous pattern, is because the wife contributes economically, even though the main breadwinner is still the husband. With his income, the wife does not fully depend on her husband. ${ }^{20}$ The wife has the power to make decisions, but the husband still has more power in his position as the main breadwinner. ${ }^{21}$

The fourth pattern is the pattern of equal partner marriage. In this pattern, the husband or wife does not indicate which position is higher or lower. The wife gets the right to develop herself fully and carry out household duties so that the husband's work is as important as the wife's work. The wife can be the main breadwinner and has a higher income than the husband's income because the reason the wife works is to be independent. ${ }^{22}$

When viewed from the pattern above, Islamic law emphasizes the pattern of head complement in the relationship of husband and wife. On the one hand, the husband must provide all the needs of his wife, but the husband is also obliged to run the household if needed. The provision of helpers is a form of the husband's responsibility to fulfill his domestic duties. According to Ibn Qudamah, the obligation to breastfeed is also the obligation of a husband who is

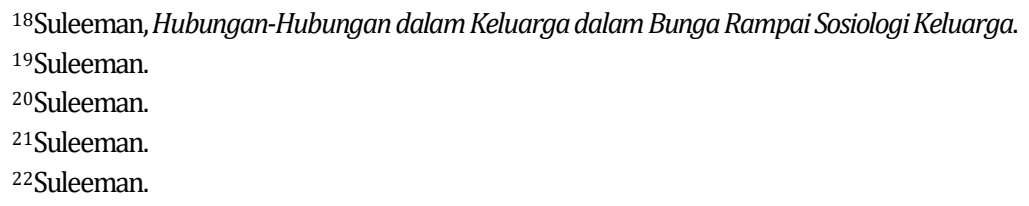


fulfilled by providing income to his wife. When the wife cannot breastfeed, the husband is obliged to find breast milk. ${ }^{23}$

\section{The Phenomenon of Migrant Workers in Indonesia}

The placement of women migrant workers abroad is a policy of the Indonesian people. The limited available employment sector and the conversion of agricultural land into housing, making the unemployment rate of citizens more and more.

Women migrant workers are faced with a role as the main supporter of family security. Women who have been called mothers, have a big task in family education and shape the character of children and hone the potential of their children. Above all activities, the role at home to educate children must not be overlooked.

The wife who is a migrant worker is faced with two problems because she cannot carry out two jobs at once. One side of the work of the employer and one side of the responsibility towards the family.

Women migrant workers have a contract with the employer following the contents of the work contract both the length of work and salary. Taiwan has a 3-years work contract with a salary of 23,800 NDT, Hong Kong a 2-year work contract with a salary of $4,530 \$$, Singapore with a 2-years work contract, and a salary of 550 SGD. Salary sent to women migrant workers is called remittances, serves to improve the family economy ${ }^{24}$ even changed the state of the country's economy. 25

The positive side of remittance plays a large role in the family economy and the social-economic cycle of the community. Previous research by the World Bank,26 Dean Yang,27 Mohammad Ziaul Haider et al.28 Council of

${ }^{23}$ Qudamah, al-Mughnī.

${ }^{24}$ Babun Niāmatur Rohmah and Riska Ayu Purnama Sari, "Tingkat Perubahan Kesejahteraan Ekonomi Keluarga Buruh Migran,” Intaj: Jurnal Penelitian Ilmiah 1, no. 1 (2017): 120-44, https://doi.org/10.35897/intaj.v1i1.79.

${ }^{25}$ Sena Gnangnon, "Export Revenue and Remittances Sent from Migrants' Host-Countries," Remittances Review 4 (2019): 12, https://doi.org/10.33182/rr.v4i1.684.

${ }^{26}$ John Page and Sonia Plaza, "Migration Remittances and Development: A Review of Global Evidence," Journal of African Economies 15, no. suppl_2 (2006): 245-336, https://doi.org/ 10.1093/jae/ej1035. 
Muktadir-al-Mukit et al,29 Bezon Kumar,30 Ambreen Anjum et al.31 Temitayo Olumide Olaniyan, ${ }^{32}$ John S. Afaha ${ }^{33}$, Nurlan Kurmanov, et al, ${ }^{34}$ Faiza Husnayeni Nahar et $\mathrm{al},{ }^{35}$ show that remittances are very positive for the development of families, communities, and countries receiving remittances. The utilization of remittances continues to develop to meet the educational needs of children ${ }^{36}$ and buy immovable assets such as land. ${ }^{37}$ The discovery of Faiza Husnayeni Nahar et al. ${ }^{38}$ Ade Eka Afriska et al. ${ }^{39}$ and Baiq Ratna Mulhimmah ${ }^{40}$ explained that between women migrant workers and remittances had a positive and

\footnotetext{
27Dean Yang, "Migrant Remittances," Journal of Economic Perspectives 25, no. 3 (September 2011): 135-36, https://doi.org/10.1257/jep.25.3.129.

28Mohammed Haider, Tanbir Hossain, and Ohidul Siddiqui, "Impact of Remittance on Consumption and Savings Behavior in Rural Areas of Bangladesh," Journal of Business 1 (2016): 32, https://doi.org/10.18533/job.v1i4.49.

${ }^{29}$ Dewan Muktadir Al-Mukit, A. Z. M. Shafiullah, and Anamul Haque Sajib, "Determination of Causality between Remittance and Import: Evidence from Bangladesh," International Journal of Business and Social Research (IJBSR) 3, no. 3 (2013): 31, https://doi.org/10.18533/ijbsr.v3i3.56.

${ }^{30}$ Bezon Kumar, "The Impact of International Remittances on Poverty Alleviation in Bangladesh," Remittances Review 4 (2019): 82, https://doi.org/10.33182/rr.v4i1.665.

${ }^{31}$ Kausar Yasmeen et al., "The Impact of Workers' Remittances on Private Investment and Total Consumption in Pakistan," International Journal of Accounting and Financial Reporting 1, no. 1 (2011): 177, https://doi.org/10.5296/ijafr.v1i1.949.

32Temitayo Olumide Olaniyan, "Interactive Effects of Remittances and Financial Sector Development on Economic Growth in Nigeria," Remittances Review 4, no. 1 (2019): 34, https:// doi.org/10.33182/rr.v4i1.677.

${ }^{33} J$ John S. Afaha, "Migration, Remittance and Development in Origin Countries: Evidence from Nigeria," African Population Studies 27, no. 1 (2013): 68, https://doi.org/10.11564/27-1-7.

${ }^{34}$ Nurlan Kurmanov et al, "Labour Migration and Remittances: Strategy for Survival or Development?," International Journal of Economics and Financial Issues 7, no. 1 (2017): 338.

35Faiza Husnayeni Nahar and Mohd Nahar Mohd Arshad, "Effects of Remittances on Poverty Reduction: The Case of Indonesia," Journal of Indonesian Economy and Business 32, no. 3 (2017): 174, https://doi.org/10.22146/jieb.28678.

${ }^{36}$ Suyanto Suyanto, "Pemanfaatan Remitan Ekonomi dan Ketergantungan Migran Kembali Bekerja di Luar Negeri," Endogami: Jurnal Ilmiah Kajian Antropologi 2, no. 1 (2018): 33, https://doi.org/10.14710/endogami.2.1.30-37.

${ }^{37}$ Anggraeni Primawati, "Remitan Sebagai Dampak Migrasi Pekerja Ke Malaysia," Sosio Konsepsia 16, no. 2 (2017): 220, https://doi.org/10.33007/ska.v16i2.804.

${ }^{38}$ Nahar and Arshad, "Effects of Remittances on Poverty Reduction: The Case of Indonesia."

${ }^{39}$ Ade Eka Afriska, T. Zulham, and Taufiq C. Dawood, "Pengaruh Tenaga Kerja Indonesia Di Luar Negeri Dan Remitansi terhadap PDB per Kapita Di Indonesia," Jurnal Perspektif Ekonomi Darussalam 4, no. 2 (July 1, 2019): 246, https://doi.org/10.24815/jped.v4i2.12947.

${ }^{40}$ Mulhimmah, "Penguatan Ekonomi Keluarga Melalui Pelatihan Pengelolaan Uang Kiriman (Remitan) pada Keluarga Buruh Migran di Desa Setanggor Kecamatan Prabaya Barat Daya Kabupaten Lombok Tengah."
} 
significant effect on Indonesia's per capita GDP. The negative side of remittance creates dependency and uses remittance by the family to support the family's needs if the husband's income is insufficient. ${ }^{41}$

Husbands who have a dependence on remittances tend to be less solutive to the family economy so that they allow their wives to return to being women migrant workers. ${ }^{42}$ Remittances were able to eliminate the grim shadows of suffering suffered by women migrant workers, replaced by monthly obligations for wives that must be sent and received by the husband. The phenomenon of women migrant workers has largely taken over the function of the mother who should be the head of the household ends up being the backbone of the family. Their main reason is first because of the crush of economic needs. ${ }^{43}$ The second cause is the trend to become migrant workers, where working as a migrant worker is a necessity, a quick solution in changing lives. ${ }^{4}$

Every government in this case PJTKI ${ }^{45}$ provides opportunities for women migrant workers in the domestic field. Many promotions offered by PJTKI to prospective women migrant worker registrants, by creating an official website so that anyone can access easily.

Prospective women migrant workers can come from education levels ranging from elementary, junior high, high school, and equivalent. The age specified by the destination country varies, depending on the destination country, for example, Hong Kong at least 21 years old, Singapore at least 23 years old, and Taiwan at least 20 years old.

The choice of job vacancies varies greatly depending on where the country is going. Figure 1, offers job choice options that are more attractive to women migrant workers.

${ }^{41}$ Muhammad Mukti Alie Bayu Diyantoro, “Pola Penggunaan Remitan Tenaga Kerja Indonesia (TKI) serta Pengaruhnya terhadap Perkembangan Daerah Asal," Teknik PWK (Perencanaan Wilayah Kota) 3, no. 2 (2014): 303.

${ }^{42}$ Suyanto, "Pemanfaatan Remitan Ekonomi dan Ketergantungan Migran Kembali Bekerja di Luar Negeri."

${ }^{43}$ Interview with ex women migrant workers informants on Wednesday, May 22, 2019.

${ }^{44}$ Interview with ex women migrant workers informants on Wednesday, May 22, 2019.

${ }^{45}$ Perusahaan Jasa Tenaga Kerja Indonesia (PJTKI). 


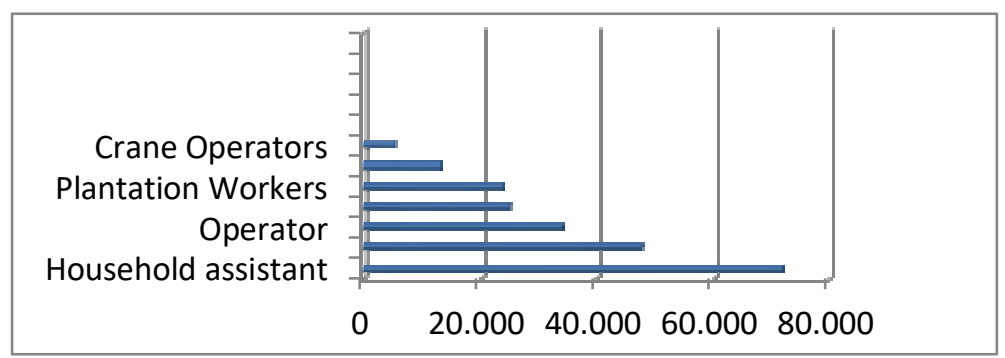

Figure 1.

Job Choices. BNP2TKI's data for January-December 2018.

\section{Islamic Norms of Working Wives}

Women working outside the home are not a new phenomenon in Islam. During the time of the Prophet, the wives of the prophet were active in various fields, both economic and professional. Siti Khadijah was a successful businessman and in her youth, the Prophet Muhammad worked for Khadijah. The wife of the Prophet Muhammad others, namely Safiyah bint Huyay works as bridal makeup, while Zainab bint Jahsh owns the home industry in the field of tanning animal skins. ${ }^{46}$

These examples above show that public activity was not a taboo during the time of the Prophet Muhammad himself. Siti Aisyah also became the leader of the war after the death of the Prophet Muhammad and became a productive narrator of the hadith. There is a spirit from the Messenger of Allah that legitimizes the public activity of the woman, namely the words of the Prophet that God likes a believer servant who can make a company. ${ }^{47}$ These examples of activities and normative grounds confirm that public activities for women are not prohibited.

The housework of a wife is a profession that is recognized in Islam. The wife is likened to a person whose rights have been detained because she has to stay at home and look after her household affairs so that she has the right to earn a living in return for being held back at home. ${ }^{48}$ The conception

${ }^{46}$ B. Syafuri, "Nafkah Wanita Karier dalam Pespektif Fikih Klasik," Ahkam: Jurnal Ilmu Syariah 13, no. 2 (2013): 201-8, https://doi.org/10.15408/ajis.v13i2.933.

47Jalāl al-Dīn al-Suyūṭi, al-Jāmi' al-Kabīr, 1st juz. (Maktabah Shāmilah, n.d.), 885.

${ }^{48}$ Abu Zahrah, al-Ahwāl al-Syahsiyah (Bairut: Dār al-Fikr al-Arabi, 1950), 232. 
emphasizes that domestic work is a form of restriction on women so that women as housewives get the right to a living. Husbands are required to ensure that working wives do not bear work that is too burdensome. If the wife is unable to fulfill her homework, the husband must teach correctly. ${ }^{49} \mathrm{~A}$ living for married women is not intended to contain them, but rather as an appreciation for women who have left their parents' homes and moved to a new family home with perfect surrender.

In that context, the wife is not obliged to look for property and her personal property becomes her own. Surah al-Nisā 'verse 34 confirms the explanation of al- Baqarah verse 233 that a legal husband is obliged to provide for his wife even though his wife has a decent job and a large salary. The husband is not encouraged to arrange and ask for his wife's salary unless his wife gives it sincerely.

Islamic law in principle also adheres to the separation between husband's property and wife's property. This principle follows the line of thought that the husband is a breadwinner, while the wife is not a breadwinner, although later the discourse about the ability of women to get involved earns.

Fiqh scholars have a different view of working wives. Mazhab Hanbali legalizes a wife who proposes to work for her husband during marriage and the husband is obliged to fulfill..$^{50}$ Fiqh scholars have a different view of working wives. Ma z hab Hanbali legalizes a wife who proposes to work for her husband during marriage and the husband is obliged to fulfill. In contrast, mazhab Shafi'i rejected any proposed laden wives who want to work, because according to qawl jadid, living with their wives must be given control of husband to wife, not because of the contract. When the wife leaves the husband's house, the wife performs nushüz (or defiance), even for religious purposes such as pilgrimage.

Mazhab Maliki took the middle road by legalizing his wife to apply for work. working wives are punished by makrūh (not recommended) so that the husband does not have to comply with these suggestions. If the wife does not accept the husband's decision, then he is considered to do nushüz.51 Thus, the husband as the leader of the wife can arrange that the wife is at home, limiting herself from all the time-consuming activities to educate children.

\footnotetext{
${ }^{49}$ al-Zuhailī, al-Fiqh al-Islām wa 'Adillatuhu.

50 al-Zuhailī.

51al-Zuhailī.
} 
The pattern of head complement appears to apply to families idealized in Islamic teachings. The wife is seen as a complement to the husband and the husband is expected to meet the needs of the wife in the form of love and affection. The husband as the head of the household and the wife are supporters and friends of communication. The husband and wife decide to arrange life together, but the husband's job is still to make a living to support the family and the wife's duty is still to manage the household and educate children. ${ }^{52}$ Relationship patterns are referred to as complementary relationship patterns.

Fiqh scholars have given answers about the existence of women who want to leave the house, there must be permission from their husbands. Wives who choose to work must get permission from their husbands. If the husband does not give permission then the wife is considered nushūz.

The phenomenon of migrant workers is contemporary. Migrant workers, as stated earlier, emerged in Indonesia in response to the economic problems faced by families. The availability of the market or the demand for labor abroad is a driving force for women to try their luck abroad to work leaving their families. Social change can affect the changes in the law so that even in Islamic law there are rules of legal change.

Islamic law views law as identified with the Bible ${ }^{53}$ (the word) of Allah, but Islamic law does not close itself to change. The idea of changing the law is clear with the existence of one of the rules of the al-qā'idah al-fiqhiyyah.

$$
\text { تغير الفتوى بحسب تغير الأزمنة والأمكنة والبيئة والأحوال والعوائد54 }
$$

Fatwas change according to changes in time, place, environment, conditions and habits

This above rule is a rule made by Ibn Qayyim al-Jauziyyah. In his introduction, he explained that this principle was very important so that failure to understand this rule could cause difficulties in understanding and implementing the Shari'a. According to Ibn Qayyim, the Shari'a was built based on human wisdom and benefit in the world and the hereafter. The foundation of the Shari'a is justice, mercy (compassion), and benefit.

\footnotetext{
${ }^{52}$ Suleeman, Hubungan-Hubungan dalam Keluarga Dalam Bunga Rampai Sosiologi Keluarga.

${ }^{53}$ al-Zuhaili, Ușūl al-Fiqh al-Islāmī.

${ }^{54}$ Ibn Qayyim Al-Jauziyah, I'lām Al-Muwaqqi'Īn (Beirut: Maktabah al-Aṣriyah, 2003), 12.
} 
Muhammad Zarqa' ${ }^{15}$ and al-Burnu ${ }^{56}$ made a rule which read:

$$
\text { تغير الأحكام بتغيرالأزمان والأمكنة والأحوال والنيات والعواعد. }
$$

Laws change according to changing times, places, conditions, intentions, and habits.

The two rules above have the same substance, namely the change in Islamic law due to several factors, al-zamān, al-makān, al-ahwwāl al-niyāh and al$\bar{a} d a h$ (time, place, circumstances, intentions and habits). It can be said simply that Islamic law can change with social change.

The question that arises is the extent to which Islamic law which is conceived as the decree of God can accommodate social change which then makes it a foothold and is considered a change in Islamic law. Are there certain boundaries that become the boundaries of the changing areas of Islamic law. Does Islamic law always follow the movement of social change or only in certain circumstances, is there any limitation provisions.

Yusuf Qardawi put forward ten factors that can encourage changes in the law, namely:57 1) Changes the place, 2) Changes age, 3) Changes in circumstances, 4) Changes in habits or 'urf, 5) Changes in the information or knowledge, 6) Changes need humans, 7) Changes in human capabilities, 8) Changes in the social, economic, and political, 9) Changes in opinions and thoughts, 10) common disaster. But according to Yusuf Qardlawi, basically only the development of conditions and customs factors that can be seen from the perspective of social change.

But the question is whether the rules of Islamic law and the precedent of the wives of the Prophet Muhammad can be used as an endorsement for migrant workers. Yusuf Qardawi put forward several factors that make the law can change, 58 but these factors do not explicitly support changes in Islamic law regarding women migrant workers.

\footnotetext{
${ }^{55}$ Ahmad Ibn Muhammad al-Zarqa', Sharh al-Qawāỉi al-Fiqhiyyah (Damaskus: Dār al-Qalam, 1989), 227.

56 Muhammad Sidqi al-Būrnū, al-Wajīz fi Ị̇̂̄ạh Qawāid al-Fiqh al-Kulliyyah (Damascus: Mu’assasat al-Risālah al-'̄̄lamìyah, 2002), 286.

57Yusūf Qarḍawī, Mūjibāt Taghayyur al-Fatwā fí Așrina, 2nd ed. (Mesir: Dār al-Shurūq, 2011), 39.

${ }^{58}$ Qarḍawī, Mūjibāt Taghayyur al-Fatwā fi Așrina.
} 
Various factors still need to be reviewed to be able to assess the phenomenon of migrant workers based on Islamic law. During the time of the Prophet Muhammad, even women who worked were still the responsibility of their husbands, while migrant workers were born because of the inability of their husbands to meet family needs adequately. Women at the time of the Prophet Muhammad worked regularly in places that were not far from their homes, while migrant workers had to leave their homes and families. They have to face the risk of heavy work in communities of different cultures and languages. The risks for women migrant workers originate from a recruitment agency. they are more concerned with the number of applicants compared to safety and work protocols for women migrant workers.

According to Haryani, ${ }^{59}$ Husna, ${ }^{60}$ and Miswanto et al.61 Nuraeny, ${ }^{62}$ and Sukesi, ${ }^{63}$ women migrant workers are prone to workplace violence. Various kinds of violence befall women migrant workers, especially gender-based violence.

Request to stop the migrant workers' shipping is impossible. What can be done is to give an understanding of the husband or father (guardian) about the dangers of working as a women migrant worker. They must be given an understanding of the risks of women migrant workers because they are far from their families and now from government monitoring because they work in the domestic sector. This is one way to close the gap so that women do not easily choose to become migrant workers.

In the fiqh study, there is the argument of sadd al-dhari'ah (closing facilities/roads) used as legal conclusions, which can serve to anticipate the

\footnotetext{
${ }^{59}$ Rizky Nur Haryani, “Tinjauan Kriminologi Kritis terhadap Kebijakan Negara dalam Melindungi Perempuan Buruh Migran Pekerja Rumah Tangga," Jurnal Kriminologi Indonesia 7, no. 2 (2011): 176.

${ }^{60}$ Nurul Husna, "Kekerasan terhadap Perempuan sebagai Pekerja Migran," Jurnal Al-Bayan: Media Kajian dan Pengembangan Ilmu Dakwah 20, no. 2 (2014): 16, https://doi.org/10.22373/ albayan.v20i30.120.

61 Miswanto Miswanto and Desmayeti Arfa, "Perdagangan dan Penyeludupan Pekerja Migran Indonesia di Malaysia," Jurnal Antropologi: Isu-Isu Sosial Budaya 18, no. 1 (2016): 1-11, https://doi.org/ 10.25077/jantro.v18.n1.p1-11.2016.

${ }^{62}$ Henny Nuraeny, "Trafficking of Migrant Workers in Indonesia: A Legal Enforcement and Economic Perspective of Prevention and Protection Efforts," European Research Studies Journal XX, no. 4B (2017): 18.

${ }^{63}$ Keppi Sukesi, "Work Condition, Gender Relation and Violence Against Women Migrant Domestic Workers," Mimbar: Jurnal Sosial dan Pembangunan 34, no. 1 (2018): 46, https:// doi.org/10.29313/mimbar.v34i1.2985.
} 
pace of development of women migrant workers. This evidence serves to prevent the use of facilities or roads that appear to change but can lead to illicit matters. Wahbah Zuhaili defines sadd al-dhari'ah is to forbid and reject everything that can be a means to haram, to prevent damage and danger. ${ }^{64}$

Sadd al-dhari'ah was placed as one of the propositions in establishing the law despite the dispute over its use. Scholars who use it fully as a method in establishing law, are mazhab Maliki and mazhab Hambali. The scholars in the mazhab Maliki developed this method in various discussions of fiqh and their ușül fiqh so that it could be applied more broadly. Imam al-Qarafi (d. $684 \mathrm{H}$ ), for example, developed this method in his book-Anwār al-Burūq fi Anwā' al-Furūq. Likewise, al-Shatibi (d. $790 \mathrm{H})$ who described this method in his book alMuwafaqat. ${ }^{65} \mathrm{Al}-$ Shațibi said that dhari'ah was:

$$
\text { إن حقيقة قائدة الذريعة هي التوصل بما هو مصلحة إلى مفسدة.65 }
$$

The essence of dhari'ah's rules is he who connects something beneficial to mafsadat (damage). That is, someone does a job that is permissible because it contains a benefit, but in the end, the goal achieved ends in a mafsadat.

Followers of the mazhab Hanbali also accept sadd al-dhari'ah as legal determination method. Followers of the Hanbali school who developed sadd aldhari'ah in their legal thinking were Ibn Qudamah (w. $62 \mathrm{H}$ ), Ibn a -Qayyim (w. $751 \mathrm{H}$ ), al-Zarkashi (w. $772 \mathrm{H}$ ) and Ibn Taimiyyah. ${ }^{67}$

Sadd al-dhari'ah is one of legal determination methods (istinbāt al-ḥukm) in Islam. Placed dhari'ah as one proposition in establishing law implies that although the personality 'does not clearly establish the law an act, because of what it defined as wasilah of an act forbidden, then this is an indication or argument that the law Watch it is as the law set by the Shariah' for the main deed.68

Sadd al-dhari'ah means that although shara 'does not clearly stipulate the law of action, because it is determined as a referee of an act which is prohibited.

\footnotetext{
64Wahbah al-Zuhaili, al-Wājiz fi Ușūl al-Fiqh (Damascus: Dār al-Fikr, 1999), 108.

65Ibrāhīm ibn Mahna ibn 'Abdilāhi ibn Mahanna, Sadd al-Dharāit' 'inda Shaikh al-Islām Ibn Taimiyyah' (Riyāụ: Dār al-Fadịlah, 2004), 66-68.

66Yusūf 'Abd al-Raḥmān al-Farat, al-Tațbīqāt al-Mu'asirāt li al-Sadd al-Dharīāt (Cairo: Dār-al-Fikr al-Arabī, 2003), 11.

67Ibn Mahanna, Sadd al-Dharāî' 'inda Shaikh al-Islām Ibn Taimiyyah,'70-74.

68al-Zuhaili, al-Wājiz fi Ușūl al-Fiquh.
} 
By using this proposition can eliminate the forbidden, immoral, or prevent the occurrence of cases that bring madarat. Qã idah fiqhiyyah which can be used as a legal basis and as a guide is:

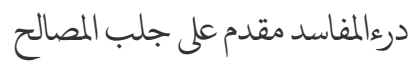

Refuse damage takes precedence over taking benefits or benefits.

The sadd al-dhari'ah argument can cut the chain of sending women migrant workers. This needs support from various elements, for example, marriages, gender-responsive private institutions, government agencies in this case the legislative council. They must be united to save the fate of human beings who are named women rather than raising the country's foreign exchange which migrant workers do not necessarily know what services are used for what purposes. The human soul must be prioritized as proof that Islam values life with hifž nafs so highly.

\section{E. Conclusion}

The purpose of forming a family is to realize the welfare of family members. A prosperous family is defined as a family that is formed based on legal marriage, can meet proper physical and mental needs, is devoted to God Almighty, and has a harmonious, harmonious, and balanced relationship between family members, and between families and the community and the environment. In the Quran, it is stated that the purpose of family is to create a happy family (sakinah mawaddah wa rahmah). This goal is created when the family's social system is filled and occupies their respective positions.

The benefit of the family is the main foundation for the benefit of society. If the household order falls apart from working abroad as a migrant worker, then all the material collected cannot replace scientific and educational activities, all economic strength and reserves cannot replace the position of the family in building an ideal society. A wife leaves home to work for years, no more noble than the responsibility of looking after her husband and educating her children.

Priority measures must remain a reference in the family. If household chores do not take up much of the wife's time, then there is no obstacle for women to use part of their time to work, regardless of the type of work they are doing as well. If working abroad for a long time disturbs the benefit of the family, then the husband and wife must consult to reach an agreement in 
applying the rules of priority scale, so that honor, harmony, and integrity of the family is maintained well. If a woman insists on working without carrying a husband's permission, the woman is considered nushūz.

The state must begin to reconsider the benefits and interpretations of sending women migrant workers. When the State still applies regulations on sending women migrant workers, the government must look back on the migrant worker protection law, because it involves the rights and obligations of women migrant workers. Among their rights and obligations is to receive a living and become the head of the household.

Opening the sending of women migrant workers is the same as opening the opportunity for a shift in livelihood responsibilities, which at first the husband's responsibility becomes the wife's responsibility. Opportunities for opening this shift must be closed so as not to cause the damage (mafsadat) which is detrimental to women. The proof that can be used is sadd al-dhari'ah, which is closing every gap/road that can cause harm even though the gap/road is originally legal.

Changes to the law on transfer of responsibilities husband to wife a living person can not be manifested in the phenomenon of women migrant workers because they still use the family's social system models head Ballsbridge. The Head complement is the wife seen as a complement to the husband. The husband is expected to meet his wife's needs for love and affection for sexual satisfaction, emotional support, friends, understanding, and open communication. The husband and wife decide to manage together life together but the husband is still earning a living to support the family and the wife's duty is still to manage the household and educate children.[s]

\section{References}

Afaha, John S. "Migration, Remittance and Development in Origin Countries: Evidence from Nigeria." African Population Studies 27, no. 1 (2013): 53-69. https://doi.org/10.11564/27-1-7.

Afriska, Ade Eka, T. Zulham, and Taufiq C. Dawood. "Pengaruh Tenaga Kerja Indonesia di Luar Negeri dan Remitansi terhadap PDB per Kapita di Indonesia." Jurnal Perspektif Ekonomi Darussalam 4, no. 2 (2019): 231-48. https://doi.org/ 10.24815/jped.v4i2.12947. 
Asih Sulistiyo, Putri, and Ekawati Sri Wahyuni. "Dampak Remitan Ekonomi terhadap Posisi Sosial Buruh Migran Perempuan dalam Rumah Tangga." Sodality: Jurnal Sosiologi Pedesaan 6, no. 3 (2014): 252-58. https://doi.org/10.22500/ sodality.v6i3.8020.

Bayu Diyantoro, Muhammad Mukti Alie. "Pola Penggunaan Remitan Tenaga Kerja Indonesia (TKI) Serta Pengaruhnya terhadap Perkembangan Daerah Asal." Teknik PWK (Perencanaan Wilayah Kota) 3, no. 2 (2014): 319-32.

al-Būrnū, Muḥammad Sidqi. Al-Wajīz fi Ị̇āḥ Qawā'id al-Fiqh al-Kulliyyah. Damascus: Mu'assasatal-Risālah al-'Ālamīyah, 2002.

al-Dimasqy, al-Imām Abī Zakariya Yahyya bin Sharaf al-Nawāwī. Rawḍhah al-Ṭālibīn. Beirut: Dār Ibn Ḥazm, n.d.

Drisko, James W., and Tina Maschi. Content Analysis. Oxford: Oxford University Press, 2016.

Gnangnon, Sena. "Export Revenue and Remittances Sent from Migrants' HostCountries." Remittances Review 4 (2019): 3-18. https://doi.org/10.33182/ rr.v4i1.684.

Haider, Mohammed, Tanbir Hossain, and Ohidul Siddiqui. "Impact of Remittance on Consumption and Savings Behavior in Rural Areas of Bangladesh." Journal of Business 1 (2016): 25. https://doi.org/10.18533/job.v1i4.49.

Haryani, Rizky Nur. "Tinjauan Kriminologi Kritis terhadap Kebijakan Negara dalam Melindungi Perempuan Buruh Migran Pekerja Rumah Tangga." Jurnal Kriminologi Indonesia 7, no. 2 (2011): 174-92.

Husna, Nurul. "Kekerasan terhadap Perempuan sebagai Pekerja Migran." Jurnal AlBayan: Media Kajian dan Pengembangan Ilmu Dakwah 20, no. 2 (2014): 11-20. https://doi.org/10.22373/albayan.v20i30.120.

Ibn Mahanna, Ibrāhīm ibn Mahna ibn 'Abdilāhi. Sadd al-Dharā'i' 'inda Shaikh al-Islām Ibn Taimiyyah. Riyāḍ: Dār al-Faḍilah, 2004.

al-Jauziyah, Ibn Qayyim. I'lām al-Muwaqqi'īn. Beirut: Maktabah al-Așriyah, 2003.

Kumar, Bezon. "The Impact of International Remittances on Poverty Alleviation in Bangladesh." Remittances Review 4 (2019): 67-86. https://doi.org/10.33182/ rr.v4i1.665.

Kurmanov, Nurlan, Saule Baktymbet, Assem Baktymbet, Assel Rakhimbekova, Gulnara Sagindykova, Aizhan Satbayeva, and Asylbek Baidakov. "Labour 
Migration and Remittances: Strategy for Survival or Development?" International Journal of Economics and Financial Issues 7, no. 1 (2017): 334-39.

Law of the Republic of Indonesia, No. 13 of 2003 concerning Manpower.

Law of the Republic of Indonesia, No. 8 of 2017 concerning Protection of Indonesian Migrant Workers.

Miswanto, Miswanto, and Desmayeti Arfa. "Perdagangan dan Penyeludupan Pekerja Migran Indonesia di Malaysia." Jurnal Antropologi: Isu-Isu Sosial Budaya 18, no. 1 (2016): 1-11. https://doi.org/10.25077/jantro.v18.n1.p1-11.2016.

al-Mukit, Dewan Muktadir, A. Z. M. Shafiullah, and Anamul Haque Sajib. "Determination of Causality between Remittance and Import: Evidence from Bangladesh." International Journal of Business and Social Research (IJBSR) 3, no. 3 (2013): 55-62. https://doi.org/10.18533/ijbsr.v3i3.56.

Mulhimmah, Baiq Ratna. "Penguatan Ekonomi Keluarga melalui Pelatihan Pengelolaan Uang Kiriman (Remitan) pada Keluarga Buruh Migran di Desa Setanggor Kecamatan Prabaya Barat Daya Kabupaten Lombok Tengah." Transformasi 10, no. 1 (2014): 14.

Nahar, Faiza Husnayeni, and Mohd Nahar Mohd Arshad. "Effects of Remittances on Poverty Reduction: The Case of Indonesia." Journal of Indonesian Economy and Business 32, no. 3 (2017): 163-77. https://doi.org/10.22146/jieb.28678.

Nuraeny, Henny. "Trafficking of Migrant Workers in Indonesia: A Legal Enforcement and Economic Perspective of Prevention and Protection Efforts." European Research Studies Journal XX, no. 4B (2017): 16-26.

Olaniyan, Temitayo Olumide. "Interactive Effects of Remittances and Financial Sector Development on Economic Growth in Nigeria." Remittances Review 4, no. 1 (2019): 19-39. https://doi.org/10.33182/rr.v4i1.677.

Page, John, and Sonia Plaza. "Migration Remittances and Development: A Review of Global Evidence." Journal of African Economies 15, no. suppl_2 (2006): 245-336. https://doi.org/10.1093/jae/ejl035.

Primawati, Anggraeni. "Remitan sebagai Dampak Migrasi Pekerja ke Malaysia." Sosio Konsepsia 16, no. 2 (2017): 209-22. https://doi.org/10.33007/ska.v16i2.804.

Qarḍawī, Yusūf. Mūjibāt Taghayyur al-Fatwā fi Așrina. 2nd ed. Mesir: Dār al-Shurūq, 2011.

Qudamah, Ibnu. Al-Mughnī. 1st juz. Beirut: Bait al-Afkār al-Dauliyah, 2004. 
al-Raḥmān al-Farat, Yusūf 'Abd. Al-Tațbìqāt al-Mu'asirāt li al-Sadd al-Dharī̄āt. Cairo: Dār-al-Fikr al-Arabī, 2003.

Rohmah, Babun Niāmatur, and Riska Ayu Purnama Sari. "Tingkat Perubahan Kesejahteraan Ekonomi Keluarga Buruh Migran." Intaj: Jurnal Penelitian Ilmiah 1, no. 1 (2017): 120-44. https://doi.org/10.35897/intaj.v1i1.79.

Sabiq, Sayyid. Fiqh Al-Sunnah. Translated by Muhyiddin Syaf. Bandung: Al-Ma'arif, 1978.

Sukesi, Keppi. "Work Condition, Gender Relation And Violence Against Women Migrant Domestic Workers." Mimbar: Jurnal Sosial Dan Pembangunan 34, no. 1 (2018): 43-50. https://doi.org/10.29313/mimbar.v34i1.2985.

Suleeman, Evelys. Hubungan-Hubungan dalam Keluarga dalam Bunga Rampai Sosiologi Keluarga. Edited by T. O. Ikhromi. Jakarta: Yayasan Obor Indonesia, 2004.

Suyanto, Suyanto. "Pemanfaatan Remitan Ekonomi dan Ketergantungan Migran Kembali Bekerja di Luar Negeri." Endogami: Jurnal Ilmiah Kajian Antropologi 2, no. 1 (2018): 30-37.https://doi.org/10.14710/endogami.2.1.30-37.

al-Suyūṭi, Jalāl al-Dīn. Al-Jāmi' Al-Kabīr. 1st juz. Maktabah Shāmilah, n.d.

Syafuri, B. "Nafkah Wanita Karier dalam Pespektif Fikih Klasik." Ahkam: Jurnal Ilmu Syariah 13, no. 2 (2013): 201-8. https://doi.org/10.15408/ajis.v13i2.933.

Yang, Dean. "Migrant Remittances." Journal of Economic Perspectives 25, no. 3 (September 2011): 129-52. https://doi.org/10.1257/jep.25.3.129.

Yasmeen, Kausar, Ambreen Anjum, Kashifa Yasmeen, and Sidra Twakal. "The Impact of Workers' Remittances on Private Investment and Total Consumption in Pakistan." International Journal of Accounting and Financial Reporting 1, no. 1 (2011): 152. https://doi.org/10.5296/ijafr.v1i1.949.

Zahrah, Abū. Al-Ahwwāl al-Shahsiyyah. Beirut: Dār al-Fikr al-'Arabi, 1950.

al-Zarqa', Aḥmad Ibn Muhammad. Sharh al-Qawā'id al-Fiqhiyyah. Damaskus: Dār alQalam, 1989.

al-Zuhailī, Wahbah. Al-Fiqh al-islām wa 'Adillatuhu. Vol. 6. Damascus: Dār al-Fikr, 1989.

___. Al-Wājiz fi Ușūl al-Fiqh. Damascus: Dār al-Fikr, 1999.

__. Ușūl al-Fiqh al-Islāmī. Damascus: Dār al-Fikr, 2009. 